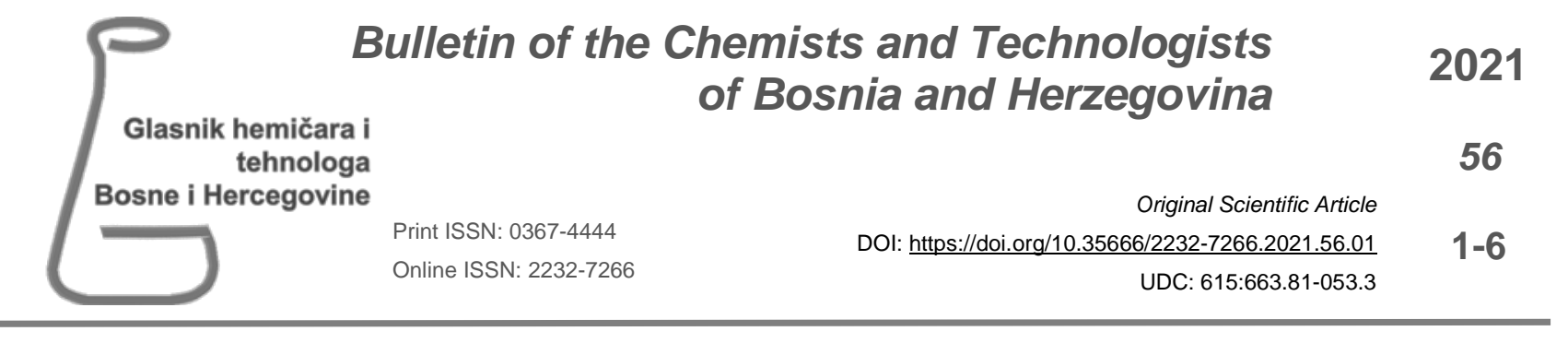

\title{
Determination of Sulfites in Fruit Juices and Meals for Infants and Toddlers
}

\author{
Marjanović, A., Đeđibegović, J., Lugušić, A., Šober, M.
}

Faculty of Pharmacy, University of Sarajevo, Zmaja od Bosne 8, 71000 Sarajevo, BiH

Article info

Received: 05/06/2020

Accepted: 09/02/2022

Keywords:

Exposure

Fruit Juice

Sulfites

Infants

Toddlers

\begin{abstract}
Sulfites have a regular application in different technological procedures during food processing, storage and distribution. Yet their use in food industry can pose potential risk for human health since they can cause a various health effects including respiratory, dermatological and gastrointestinal signs and symptoms. Regulation regarding additive use in food in Bosnia and Herzegovina is in accordance with the EU Regulation 1333/2008. Since these bylaws do not allow a presence of sulfites in food products for children the aim of this work was to inspect some of commercially available foods intended for children $(\mathrm{N}=14)$ in order to determine content of sulfites and also to estimate possible exposure. Sulfites were determined by modified spectrophotometric method, upon releasing sulfur dioxide by acid addition and its capture in chloromercurate solution. Proposed analytical method had good linearity (R2=0.999), LOD= $0.090 \mathrm{mg} / \mathrm{L}$ and $\mathrm{LOQ}=0.271 \mathrm{mg} / \mathrm{L}$, and recovery in range from $94.08 \%$ to $103.5 \%$. The content of SO2 was lower than LOQ in two samples (vegetable meal). In the rest of the samples, SO2 content was in range 1.82 to $23.6 \mathrm{mg} / \mathrm{L}$. All calculated mean estimates of dietary exposure to sulfites were well below the ADI for both groups, infants and toddlers.
\end{abstract}

*Corresponding author:

Aleksandra Marjanović

E-mail: aca1902@gmail.com

Phone: 00-387-61-70956 enzymes (including proteases, oxidases and peroxidases) thus preventing enzymatic browning during preparation, storage and distribution, and also can be used as bleaching agents in some types of food (Gould and Russell, 2003; Santos, Nunes, Saraiva, et al., 2012).

Sulfites and sulfiting agents are usually added in small amounts (ppm), and at these levels are generally harmless to the vast majority of consumers. Low levels of sulfur dioxide can also be produced naturally by yeast during fermentation, and can be present in various foods and beverages. Sulfites do not accumulate in the human body, because of the rapid biotransformation to sulfate metabolites, which are excreted via urine, thus chronic effects are not to be expected (Garcia-Fuentes, Wirtz, Vos, et al., 2015). The EFSA concluded that based on available results of chronic, carcinogenicity and reprotoxicity studies after oral exposure to sulfites, there are no reported effects, and there is no concern with antimicrobial agent to control spoilage of food. Sulfites are able to inhibit the action of a wide variety of 
respect to genotoxicity. (EFSA, 2016) Adverse effects connected with the ingestion of sulfites or sulfiting agents occur mostly in individuals sensitive to sulfites. It is estimated that $3-10 \%$ of all asthmatics are sensitive to sulfites (Timbo, Koehler, Wolyniak, et al., 2004; EFSA, 2016), experiencing asthmatic reactions and bronchospasm after ingestion of food containing sulfites. It seems that the severity of adverse reactions varies, and those asthmatics on steroid therapy or with marked airway hyper responsiveness, and especially children with the diagnosis of chronic asthma, are at greater risk. (Vally, Misso, Madan, 2009) Other adverse reactions including anaphylactic reactions, dermatitis, urticaria, irritation of the respiratory and gastrointestinal tract, can be seen in non-sensitive individuals. The conclusion of the European food safety agency (EFSA) Panel on Food Additives and Nutrient Sources added to Food is that adverse reactions on sulfites as additives in food were not immune-mediated, and were mostly intolerance reactions (EFSA, 2016).

Sulfur dioxide-sulfites (E 220-228) are authorized in the EU according to Annex II to Regulation (EC) No 1333/2008 on food additives, with maximum permissible levels (MPLs) set on the amount of residual sulfur dioxide (ppm). Levels of sulfur dioxide above $10 \mathrm{ppm}$ are subjected to mandatory labelling (EC, 2008; EC, 2011). Joint FAO/WHO Expert Committee on Food Additives (JECFA) on the safe use of food additives defined an acceptable daily intake (ADI) of sulfites (expressed as sulfur dioxide) as $0.7 \mathrm{mg} / \mathrm{kg}$ body weight (FAO/WHO, 2009). Regulation regarding additive use in food in Bosnia and Herzegovina (BiH) is in accordance with the aforementioned EU Directive (Rulebook, 2018). The use of additives, including sulfites is not allowed in foods for infants and toddlers. According to some previously conducted surveys on sulfite intake in different population groups, fruit juices are one of the most important sources of exposure to sulfites in children (FAO/WHO, 2009).

Thus, bearing in mind that children may be at higher risk due to their higher intake of food per kg body weight, in this work we have analyzed samples of commercially available ready to use fruit juices and meals for infants and toddlers in order to determine the content of sulfites in these products and to estimate possible exposure.

\section{EXPERIMENTAL}

In this work, a total of 14 samples of ready-made foods for infants and toddlers were examined, 11 samples of fruit juices (6 samples of apple juice, 2 samples of orange juice, 2 samples of banana juice and one mixed red fruits juice) and three baby meals (two with mixed vegetables and one with rice and banana).

All the collected samples were ready to use juices and meals, and were purchased from the market in Sarajevo, Bosnia and Herzegovina.

\section{Materials}

All chemicals were of analytical grade. The nitrogen gas was over $98 \%$ pure. The water was obtained from a Millipore Milli-Q water purification system. All glassware was cleaned and rinsed with double distilled water prior to use. The TCM (sodium tetrachloromercurate) solution was prepared by measuring $23.4 \mathrm{~g}$ of sodium chloride and $54.3 \mathrm{~g}$ of mercury (II) chloride in a volumetric flask of $2 \mathrm{~L}$ and dissolving with ultrapure water to mark. In order to construct calibration curve, standard stock solution of sulfites (equal to $193.6 \mathrm{mg} / \mathrm{L} \mathrm{SO}_{2}$ ) was diluted to get final standard concentrations of: $0 \mathrm{mg} / \mathrm{L} ; 0.121 \mathrm{mg} / \mathrm{L}$; $0.484 \mathrm{mg} / \mathrm{L} ; 0.726 \mathrm{mg} / \mathrm{L}$ and $2.42 \mathrm{mg} / \mathrm{L}$ expressed as $\mathrm{SO}_{2}$.

\section{Method}

In this study, we have used a conventional spectrophotometric method for the detection of sulfur dioxide in the atmosphere (Dasgupta, DeCesare, Ulrey, 1980), which was modified for the determination of sulfites in foods.

For that purpose, we have validated the modified method, and parameters such as linearity range, accuracy, precision, limit of detection (LOD) and limit of quantification (LOQ) were analyzed and detected.

LOD and LOQ were calculated from the calibration curve using equations 1 and 2:

$$
\begin{aligned}
& \mathrm{LOD}=3 \mathrm{SD} / \mathrm{S} \\
& \mathrm{LOQ}=10 \mathrm{SD} / \mathrm{S}
\end{aligned}
$$

Where SD is the standard deviation of the response based on the residual standard deviation of the regression line, and $\mathrm{S}$ is the slope of the calibration curve.

Precision (repeatability) was tested by consecutive measurement of 6 apple juice sample spiked with 0,500 $\mathrm{mg} / \mathrm{L} \mathrm{SO}_{2}$ and expressed as the coefficient of variation (CV) calculated with formula in equation 3.

$$
\text { CV }(\%)=\text { SD x 100/Mean }
$$

To determine the accuracy of the used method expressed as recovery factor (\%) we have prepared 3 spiked samples (banana juice, mixed red fruits juice and orange juice) with a known amount $(0.5 \mathrm{~mL})$ of the standard solution of sulfites (equal to $193.6 \mathrm{mg} / \mathrm{L} \mathrm{SO}_{2}$ ).

\section{Analysis of samples}

In a glass apparatus shown in Figure 1, $100 \mathrm{~mL}$ of sample was measured, then $10 \mathrm{~mL}$ of hydrochloric acid was added and the apparatus was immediately closed. Nitrogen was aspirated through the sample for 20 minutes with a flow rate of $100 \mathrm{~mL} /$ minute. On the other end of the apparatus was an absorption bottle with 20 $\mathrm{mL}$ of TCM solution. An aliquot $(5 \mathrm{~mL})$ of this solution was transferred in a volumetric flask $(50 \mathrm{~mL})$ and treated with $5 \mathrm{~mL}$ of $0.01 \%$ solution of pararosaniline and 10 $\mathrm{mL}$ of formaldehyde (0.015 \% solution). Samples were 
left on a dark place for 30 minutes, and then the absorbance on $550 \mathrm{~nm}$ was measured.

In order to prepare the calibration curve, five standard solution of sulfite-TCM were prepared and were treated on the same way as it was described for the samples. A calibration curve was prepared by plotting the absorbance values against sulfur dioxide concentration.

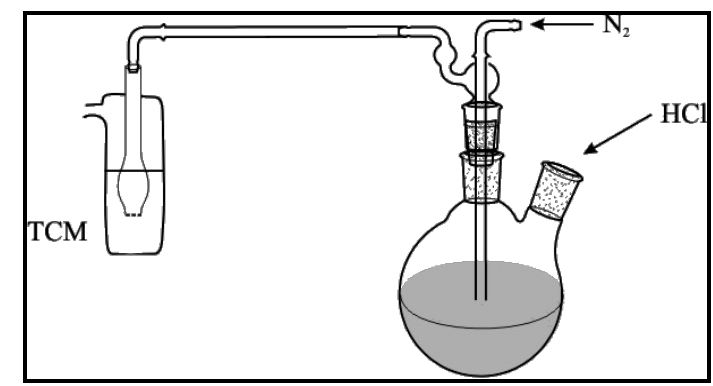

Figure 1. Glass apparatus used for determination of sulfites in samples

Bearing in mind that sulfites, when consumed, may trigger different types of allergic reactions, especially in children, consumption of samples analyzed in this study can pose a risk. Thus, we have calculated the risk as \% of ADI, by comparing estimated daily exposure to sulfites in the population of infants and toddlers with respective ADI value. Estimated daily intake $(\mathrm{mg} / \mathrm{kg}$ body weight/day) was calculated with the formula in equation 4.

$$
\mathrm{EDI}=\Sigma(\mathrm{Ci} \times \mathrm{Fi}) / \text { b.w. }
$$

Where EDI (mg/kg body weight/day) is the daily intake of the sulfites, $\mathrm{Ci}$ is the mean concentration of the sulfites in each food class $(\mathrm{mg} / \mathrm{L}$ or $\mathrm{mg} / \mathrm{kg}$ ), Fi is the individual daily consumption of each food class (mL/day) and b.w. is the average body weight $(\mathrm{kg})$.

For the calculation of EDI we have used the intake scenario with the average intake. Most of the recommendations for the daily intake of fruit juices in countries within EU vary from $25-30 \mathrm{~mL}$ to $150 \mathrm{~mL}$. (Grammatikaki, Wollgast, Caldeira, 2019). Since, there is a lack of data regarding the dietary habits of the population in Bosnia and Herzegovina, especially in this population, for the $\mathrm{Fi}$ in calculations we have used the usual serving size of juices (100 mL) and meals (100 g). (EFSA, 2012). Two calculations were made for the group of infants (0-12 months), where the average body weight was $5 \mathrm{~kg}$, and for the group of toddlers (1-3 years) with the average body weight of $12 \mathrm{~kg}$, based on the recommendations of European Food Safety Authority (EFSA). (EFSA, 2012)

\section{RESULTS}

The linearity of the used method was tested with series of five standard solutions. The calibration curve is presented in Figure 2.

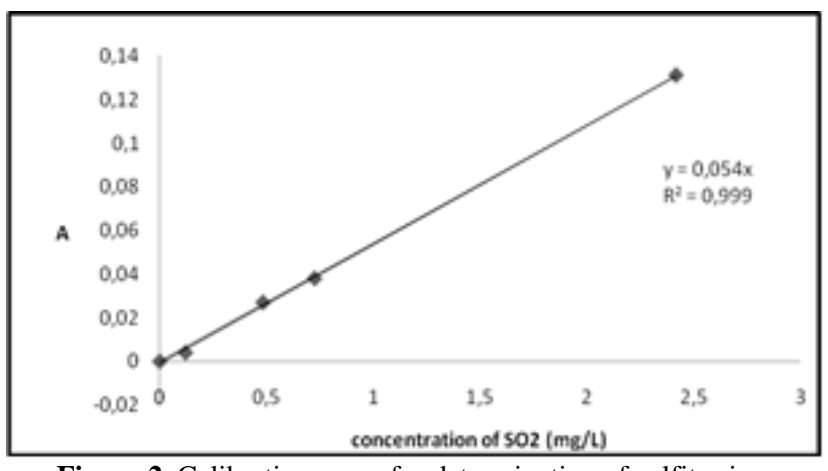

Figure 2. Calibration curve for determination of sulfites in samples

Details for analyzed method validation parameters are presented in Table 1.

Table 1. Method validation parameters

\begin{tabular}{lc}
\hline Validation parameter & Value \\
\hline Linearity & $\mathrm{R}^{2}=0.999$ \\
Precision & $\mathrm{CV}(\%)=3.89$ \\
Accuracy & Recovery (\%) \\
spiked sample 1 & 95.96 \\
spiked sample 2 & 94.08 \\
spiked sample 3 & 103.5 \\
LOD & $0.090 \mathrm{mg} / \mathrm{L}$ \\
LOQ & $0.271 \mathrm{mg} / \mathrm{L}$ \\
\hline
\end{tabular}

All the samples were analyzed in duplicate, and results are presented as the mean value.

The results of measurement are presented in Table 2 .

Table 2. Content of sulfites (mg $\mathrm{SO}_{2} / \mathrm{L}$ ) in analyzed samples (mean \pm STD)

\begin{tabular}{lcc}
\hline Sample & $\begin{array}{c}\mathrm{mg} \mathrm{SO} / \mathrm{L} \\
(\text { mean } \pm \text { STD })\end{array}$ & $\mathrm{CV}(\%)^{\mathrm{a}}$ \\
\hline
\end{tabular}

\section{Ready to drink fruit juice}

$\begin{array}{lcc}\text { banana } & 14.8 \pm 0.09 & 0.61 \\ \text { banana } & 11.2 \pm 0.02 & 0.18 \\ \text { mixed red fruits } & 1.82 \pm 0.005 & 0.27 \\ \text { orange } & 6.77 \pm 0.01 & 0.15 \\ \text { orange } & 7.14 \pm 0.02 & 0.28 \\ \text { apple } & 9.46 \pm 0.03 & 0.32 \\ \text { apple } & 11.2 \pm 0.01 & 0.09 \\ \text { apple } & 9.15 \pm 0.02 & 0.22 \\ \text { apple } & 8.05 \pm 0.03 & 0.37 \\ \text { apple } & 10.3 \pm 0.02 & 0.19 \\ \text { apple } & 9.15 \pm 0.03 & 0.33\end{array}$

\section{Ready to use meal}

\begin{tabular}{lcc} 
mixed vegetable & $0.20 \pm 0.00^{\mathrm{b}}$ & 0.00 \\
mixed vegetable & $0.19 \pm 0.001^{\mathrm{b}}$ & 0.53 \\
rice with banana & $23.6 \pm 1.22$ & 5.17 \\
\hline
\end{tabular}

aThe coefficient of variation between analytical duplicates of the fruit juice samples

${ }^{\mathrm{b}}$ bellow LOQ 
For the calculation of the risk associated with consumption of analyzed samples of fruit juices and meals we compared estimated daily intake (g or $\mathrm{mL} / \mathrm{kg}$ body weight/day) with the ADI for the sulfites in two groups of consumers, infants and toddlers. For the calculation mean concentration of sulfites in each group of samples was used. The results are expressed as \% of ADI, and are presented in Table 3.

Table 3. Estimated daily intake (mg/kg body eight/day) of sulfite and \% ADI

\begin{tabular}{|c|c|c|c|c|}
\hline \multirow[b]{2}{*}{ Sample } & \multicolumn{2}{|c|}{$\begin{array}{c}\text { Infants (0-12 } \\
\text { months) }\end{array}$} & \multicolumn{2}{|c|}{$\begin{array}{c}\text { Toddlers (1-3 } \\
\text { years) } \\
\end{array}$} \\
\hline & $\begin{array}{c}\text { EDI } \\
\mathrm{mg} / \mathrm{kg} \\
\text { body } \\
\text { weight/day }\end{array}$ & $\begin{array}{l}\% \\
\text { ADI }\end{array}$ & $\begin{array}{c}\text { EDI } \\
\mathrm{mg} / \mathrm{kg} \\
\text { body } \\
\text { weight/day }\end{array}$ & $\begin{array}{l}\% \\
\mathrm{ADI}\end{array}$ \\
\hline \multicolumn{5}{|c|}{ Ready to drink fruit juice } \\
\hline $\begin{array}{l}\text { banana } \\
\text { mixed red } \\
\text { fruits } \\
\text { orange } \\
\text { apple }\end{array}$ & $\begin{array}{l}0.04 \\
0.14 \\
0.19\end{array}$ & $\begin{array}{l}5.20 \\
19.9 \\
27.3\end{array}$ & $\begin{array}{l}0.02 \\
0.06 \\
0.08\end{array}$ & $\begin{array}{l}2.17 \\
8.27 \\
11.4\end{array}$ \\
\hline \multicolumn{5}{|c|}{ Ready to use meal } \\
\hline $\begin{array}{l}\text { mixed } \\
\text { vegetable }\end{array}$ & 0.00 & 0.54 & 0.00 & 0.22 \\
\hline $\begin{array}{l}\text { rice with } \\
\text { banana }\end{array}$ & 0.47 & 67.5 & 0.20 & 28.1 \\
\hline
\end{tabular}

\section{DISCUSSION}

The proposed modified method for the detection of sulfites in foods in this study showed a wide linear range (0.0-2.4 $\mathrm{mg} / \mathrm{L} \mathrm{SO}_{2}$ ), with the linear regression coefficient of 0.999 . The recoveries for all tested samples were acceptable (94.08-103.5) and in agreement with those reported by $\mathrm{Li}$ and Zhao (2006) for the modified p-rosaniline-formaldehyde method.

The precision of the method was good and below $5 \%$. The calculated LOD and LOQ $(0.090$ and $0.271 \mathrm{mg} / \mathrm{L}$, respectively) of the tested method reflect good suitability for the determination of low levels of sulfites in different food samples.

The content of sulfites in analyzed samples, expressed as sulfur dioxide, ranged from $0.19 \mathrm{mg} / \mathrm{L} \mathrm{SO}_{2}$ in ready to use vegetable meal to $23.6 \mathrm{mg} / \mathrm{L} \mathrm{SO}_{2}$ in a meal with rice and banana (Table 2). The average content of sulfites in fruit juice samples was $9.0 \mathrm{mg} / \mathrm{L} \mathrm{SO}_{2}$, ranging from 1.82 $\mathrm{mg} / \mathrm{L}$ in mixed red fruits juice to $14.8 \mathrm{mg} / \mathrm{L} \mathrm{SO}_{2}$ in the banana juice. In four out of 11 samples of fruit juices, the content of sulfites was above the regulation limit of $10 \mathrm{mg} / \mathrm{L} \mathrm{SO}_{2}$ (Table 2). This content was far below the content of sulfites found in similar samples (Machado, Toledo, Almeida, et al., 2008). The content of sulfites in ready to use meals was above the regulation limit only in one sample (23.6 mg/L $\left.\mathrm{SO}_{2}\right)$. In two samples of vegetable meals, the content of sulfites was below LOQ of the proposed method.

According to EU regulation on food additives content of not more than $10 \mathrm{mg} / \mathrm{L}$ is not considered to be present. When the content of sulfites exceeds this concentration, EU law requires food labels to indicate "contains sulfites" without specifying the amount (EC, 2008). None of the analyzed samples were declared to contain sulfites.

Although the content of sulfites in most of the analyzed samples was below the regulation limit, EU directive and also national legislation in $\mathrm{BiH}$, banned the use of additives in food for infants and toddlers. This means that almost all analyzed samples, except two meals with the content below LOQ, do not comply with the regulation requirements (EC, 2011; Rulebook, 2018).

The overall exposure to sulfites did not exceed the ADI. All calculated mean estimates of dietary exposure to sulfites were well below the ADI for both groups, infants and toddlers $\left(0.00-0.47 \mathrm{mg} / \mathrm{kg}\right.$ body weight day $^{-1}$ and $0.00-0.20 \mathrm{mg} / \mathrm{kg}$ body weight day $^{-1}$, respectively). This is similar to results reported in some previous studies (Mischek and Krapfenbauer-Cermak, 2012; Bemrah, Leblanc, Volatier, 2008; Soubra, Sarkis, Hilan, 2007; Leclercq, et al., 2000).

The highest risk was correlated to consumption of ready to use meal with rice and banana, where consumption of $100 \mathrm{~g}$ in infants would lead to $67.5 \%$ of ADI and also banana fruit juice (37.1 \% of ADI). The higher risk in group of infants is due to lower body weight.

Based on these results, calculated on an average intake, some high-end consumers can exceed ADI, especially if the content of sulfites is above MRL. However, the estimated intake levels of sulfites from fruit juices were low in both age groups and are within safe levels.

\section{CONCLUSION}

This study is to our knowledge, the first survey on levels of sulfites in foods for infants and young children in Bosnia and Herzegovina.

Despite the small sample size, results add to a base of knowledge in this field. It is obvious that there is a need to conduct further investigations on dietary intake and risk assessment of additives in foods, especially for the most sensitive populations groups.

\section{ACKNOWLEDGEMENT}

The study was self-supported and no financial favors were taken from any institution or company. 


\section{REFERENCES}

Bemrah, N., Leblanc, J.C., Volatier, J.L. (2008). Assessment of dietary exposure in the French population to 13 selected food colours, preservatives, antioxidants, stabilizers, emulsifiers and sweeteners. Food Additives \& Contaminants: Part B: Surveillance, 1(1), 2-14.

Dasgupta, P. K., DeCesare, K., Ulrey, J.C. (1980). Determination of atmospheric sulfur dioxide without Tetrachloromercurate (II) and the mechanism of the Schiff reaction. Analytical Chemistry, 52, 1912-1922.

[EC] European Commission. (2008). Commision Regulation (EC) No 1333/2008 of 16 December 2008 on food additives. Official Journal of the European Union, L354:16.

[EC] European Commission. (2011). Commision Regulation (EC) No 1129/2011 of 11 November 2011 amending Annex II to Regulation (EC) No 1333/2008 of the European Parliament and of the Council by establishing a Union list of food additives. Official Journal of the European Union, L295/1.

EFSA ANS Panel (EFSA Panel on Food Additives and Nutrient Sources Added to Food). (2016). Scientific Opinion on the re-evaluation sulfur dioxide (E 220), sodium sulfite (E 221), sodium bisulfite (E 222), sodium metabisulfite (E 223), potassium metabisulfite (E 224), calcium sulfite (E 226), calcium bisulfite (E 227) and potassium bisulfite (E 228) as food additives. EFSA Journal, 14(4), 4438.

EFSA Scientific Committee. (2012). Guidance on selected default values to be used by the EFSA Scientific Committee, Scientific Panels and Units in the absence of actual measured data. EFSA Journal, 10(3), 2579.

FAO/WHO. (2009). Safety evaluation of certain food additives/prepared by the sixty-ninth meeting of the Joint FAO/WHO Expert Committee on Food Additives (JECFA). World Health Organization

Garcia-Fuentes A. R., Wirtz S., Vos, E., Verhagen, H. (2015). Short Review of Sulphites as Food Additives. European Journal of Nutrition \& Food Safety, 5(2), 113-120.

Gould, G.W., Russell, N.J. (2003). Sulfite. In: Russell, N.J. \& Gould, G.W. (Eds.). Food Preservatives. (p.p. 85-101). Springer, Boston, MA.
Grammatikaki, E., Wollgast, J., Caldeira, S. (2019). Feeding infants and young children. A compilation of national food-based dietary guidelines and specific products available in the EU market; PUBSY No. 115583.

Leclercq, C., Molinaro, M.G., Piccinelli, R., Baldini, M., Arcella, D. et al. (2000). Dietary intake exposure to sulphites in Italy-analytical determination of sulphitecontaining foods and their combination into standard meals for adults and children. Food Additives and Contaminants, 17(2), 979-989.

Li, Y., Zhao, M. (2006). Simple methods for rapid determination of sulfite in food products. Food Control, 17, 975-980.

Machado, R. M. D., Toledo, M.C.F., Almeida C.A.S., Vicente, E. (2008). Analytical determination of sulphites in fruit juices available on the brazilian market. Brazilian Journal of Food Technology, 11(3), 226-233.

Mischek, D., Krapfenbauer-Cermak, C. (2012). Exposure assessment of food preservatives (sulphites, benzoic and sorbic acid) in Austria. Food Additives \& Contaminants: Part A, 29(3), 371-382.

Rulebook on Food Additives. (2018). Official Gazette of $\mathrm{BiH}, 33 / 18$

Santos, M. C., Nunes, C., Saraiva J. A., Coimbra M. A. (2012). Chemical and physical methodologies for the replacement/ reduction of sulfur dioxide use during winemaking: review of their potentialities and limitations. European Food Research and Technology, 234, 1-12.

Soubra, L., Sarkis, D., Hilan, C., Verger, Ph. (2007). Dietary exposure of children and teenagers to benzoates, sulphites, butylhydroxyanisol (BHA) and butylhydroxytoluen (BHT) in Beirut (Lebanon). Regulatory Toxicology and Pharmacology, 47, 68-77.

Timbo, B., Koehler, K.M., Wolyniak, C., Klontz, K.C. (2004). Sulfites: A Food and Drug administration review of recalls and reported adverse events. Journal of Food Protection, 67 (8), 1806-1811.

Vally, H., Misso, N.L.A., Madan, V. (2009). Clinical effects of sulphite additives. Clinical \& Experimental Allergy, 39, 1643-1651. 


\section{Summary/Sažetak}

Sulfiti imaju značajnu primjenu u različitim tehnološkim procedurama tokom proizvodnje hrane, skladištenja i distribucije. Ipak njihova primjena u prehrambenoj industriji može predstavljati potencijalni rizik po zdravlje konzumenata, pošto mogu izazvati različite neželjene efekte na zdravlje, koji se mogu ispoljiti na nivou respiratornog trakta, kože ili gastrointestinalnog trakta. Zakonske odredbe koje se odnose na upotrebu aditiva u hrani u Bosni i Hercegovini usklađene su sa odredbama EU Direktive 1333/2008. Ove odredbe zabranjuju upotrebu sulfita kao aditiva u hrani za dojenčad i malu djecu, pa je cilj ovog rada bio ispitati prisustvo i sadržaj sulfita u komercijalnim proizvodima namijenjenim djeci ( $N=14)$, kao i procijeniti moguće izlaganje. Sulfiti u izabranim uzorcima određeni su modificiranom spektrofotometrijskom metodom, detekcijom oslobođenog sumpor dioksida. Predloženi analitički metod pokazao je dobru linearnost $\left(\mathrm{R}^{2}=0,999\right)$, $\mathrm{LOD}=0,090 \mathrm{mg} / \mathrm{l}, \mathrm{LOQ}=0,271 \mathrm{mg} / \mathrm{l}$ tačnost (recovery) u rasponu od 94,08\% do 103,5 \%. Sadržaj mjerenog $\mathrm{SO}_{2}$ bio je niži od LOQ u dva uzorka (kašica sa povrćem). U ostalim uzorcima sadržaj $\mathrm{SO}_{2}$ bio je u rasponu od 1,82 do 23,6 mg/l. Procijenjeni izračunati nivoi izlaganja sulfitima za obje dobne grupe, dojenčad i malu djecu bili su ispod prihvatljivog dnevnog unosa (ADI). 